\title{
Problems faced by gen Y in recruitment processes and HRM mistakes
}

\author{
Onur Sarıkaya ${ }^{1}$ \\ ${ }^{1}$ MSc, Lecturer, Süleyman Demirel University, Isparta/Turkey, e-mail: onursarikaya1993@gmail.com, ORCID: https://orcid.org/0000-0002- \\ 0825-9573
}

\begin{tabular}{|c|c|}
\hline Article Info & Abstract \\
\hline $\begin{array}{l}\text { Research Article } \\
\text { Received: } 21 \text { October } 2021 \\
\text { Revised: } 22 \text { December } 2021 \\
\text { Accepted: } 25 \text { December } 2021 \\
\text { Keywords: } \\
\text { HRM, } \\
\text { Recruitment Processes, } \\
\text { Gen Y, } \\
\text { HRM Mistakes }\end{array}$ & $\begin{array}{l}\text { The aim of this qualitative study is to draw attention to the problems Gen Y faced in recruit- } \\
\text { ment practices and HRM mistakes committed by businesses in these processes. Web-based } \\
\text { interviews held with } 12 \text { Gen Y members. Interview notes were subjected to thematic analysis } \\
\text { and main problems encountered during the recruitment processes were identified. Findings } \\
\text { show Gen Y encounters ethical, communication, and process management problems in re- } \\
\text { cruitment processes. Recruitment process is the first stage in which employer brand value is } \\
\text { perceived, and it needs to be managed carefully. Furthermore, it will be increasingly im- } \\
\text { portant to align Gen Y's new knowledge, attitudes, values, and skills with existing work con- } \\
\text { texts. Results provide some clues to better understand perception of Gen Y and also empha- } \\
\text { size the need to update HRM practices. }\end{array}$ \\
\hline
\end{tabular}

\section{Introduction}

The term generation is used to define the group made of individuals at similar ages, have undergone similar social changes and developments, sharing a common cultural and collective memory (Smola and Sutton, 2002; Yi et al., 2015). Although there are different opinions about today's generations and age groups used in determining generations (Wong et al., 2008), there are five generations that are commonly accepted in the related literature. These are Silent Generation (1921-1940), Baby Boomers (1941-1960), Generation X (1961-1980), Millennials or Generation Y (1981-2000) and Generation Z (2001 and after) (Arsenault, 2004; Lamm and Meeks, 2009; Reeves and Oh, 2008; Strauss and Howe, 1991).

According to the theoretical approach to the concept of generation, changes in significant historical events, social, economic and/or technologic processes affect individuals in many ways; developments in these areas shape behavioral characteristics of societies. Based on this viewpoint, it can be said that individuals who were born and grow in a similar time zone have similar behavioral characteristics. On the other hand, these characteristics may change with new generations (Mannheim, 1952; Inglehart, 1977; Strauss and Howe, 1991). The world of business is the most convenient environment for analyzing differences in generations.

Generation Y (Gen Y) approximately forms one-third of today's workforce and it is estimated that the generation will form two-third of the workforce in ten years. Gen Y has thus become a significant topic in human resources (HR) literature, especially with its different behavioral characteristics. The educational level of this generation, born in a period between the beginning of the 1980s and the end of the 1990s, is quite high. Gen Y prefers flexible working conditions and gives more importance to business-daily life balance when compared to the preceding generation (Ng et al., 2010). Personal development, a meaningful job, freedom, entertainment, cooperation, innovation, and speed are the interests of this generation who find contribution to society, well-parenting and balanced life are motivating (Hiltrop, 1999; Tapscott, 2009; Hurst and Good, 2009). They prefer more humancentered businesses with powerful employer brands in business life and they prioritize the happiness of employees. Developing Human Resource Management (HRM) understandings and practices that will attract Gen Y and increase their commitment have recently become more important (Kultalahti and Viitala, 2015). D'Netto and Ahmed (2012) state that individuals of Gen Y, who were born into technology, challenge managers and it is important to

\footnotetext{
* This research has Ethics Committee Approval from Akdeniz University with 03/05/2019 date and 104 number.

To cite this article: Sarkkaya, O. (2022). Problems faced by gen Y in recruitment processes and HRM mistakes. International Journal of Social Sciences and Education Research, 8 (1), 44-50. DOI: https://doi.org/10.24289/ijsser.1012925
} 
understand their viewpoint which is different from the preceding generation in order to be successful. Similarly, Imperatori and Bissola (2010) mention that developing effective work arrangements for Gen Y is highly important for sustainability of firm competitive advantage.

Some of the researches on the relationship between Gen Y and HRM practices are about the difficulties in the employment of these individuals and keeping them in a job (Drago and Cunningham, 2006; Luscombe et al., 2013; Ng et al., 2010; Pinzaru et al., 2017). In their research, Ng et al. (2010) point out that Gen Y prioritizes businessdaily life balance and rapid progress in their career while Pinzaru et al. (2017) state that these individuals give importance to professional and personal development, innovation and employee satisfaction. A variety of researchers have been studying the differences in career beliefs and expectations of Gen $\mathrm{Y}$ when compared to the preceding generation (Dries et al., 2008; De Hauw and De Vos, 2010). Ng and Parry (2016) emphasize the views defending that analyzing intergenerational differences in terms of work ethics, attitudes and career expectations is important in revising the current HRM policies and practices. It is crucial to better understand the expectations, needs, and perceptions of Gen Y for an efficient HRM. Results of detailed researches on the issue have become more and more important for organizing and developing the practices in HRM.

The purpose of this study is to attract attention to the deficiencies in the current practices and understandings in recruitment processes, which is relatively less analyzed; the study focuses on the experiences of Gen $\mathrm{Y}$ in recruitment processes. Recruitment and selection processes can be examined through different perspectives such as applicant, recruiter, and employer (Carless, 2007). Analyzing Gen Y experiences in recruitment processes from the perspective of Recruiter can give some clues about the insufficiencies and dysfunctions in HR practices. The results of these analyses can contribute to the literature and practitioners working for improving HR practices and understandings.

\section{Gen $Y$ in the recruitment processes}

Recruitment processes involve organizational practices and policies developed for supporting applications, ensuring a constant qualified candidate pool and motivating the best candidates. Recruiting perfect candidates and keeping them are crucial points for organizational success (Luscombe et al., 2013). Having perfect employees is considered to be the most important impulsion for future organizational efficiency (Warmerdam et al., 2015). When a candidate experiences a negative recruitment process in a company, he/she forms a completely negative viewpoint about that company from the very beginning (Loiacono et al., 2011).

Expectations of Gen Y, which has become increasingly important in business life, are different from the preceding generation and these expectations have naturally changed the perspectives of young candidates in terms of recruitment processes. Eisner (2005) specifically mentions that traditional recruitment and selection processes are no longer reliable for this generation and new processes shall be created. Bosco and Harvey (2013) state that multiple practices are necessary to attract candidates to the job opening in HR departments; according to the researchers, a single type of recruitment process is not sufficient for a generation. Using digital literacy skills for information and socialization, Gen Y (Pinzaru et al., 2017) also known as Techno Savvy, prefers immediate application and response. Old fashioned prizes, traditional career opportunities, reaching career goals over a long period are no longer attractive to the members of this generation; this is why, enterprises should create specifically designed recruiting messages that will attract these individuals who are looking for a self-building job (Huybers, 2011).

The context of Gen Y in Turkey is different from other countries; 35\% of the population in the country is Gen Y (Adıgüzel et al., 2014). On the other hand, the youth unemployment rate in Turkey is $27.4 \%$ by 2019 according to the Turkish Statistical Institute (2019). According to this highly concerning data, it can be said that almost one out of every three Turkish youths is unemployed. According to the results of Gen Y research by Deloitte (2018), $50 \%$ of the currently working young population in Turkey wants to change his/her job. These rates indicate that Gen Y in Turkey is in a constant process of job-searching. As most of the businesses in Turkey are SMEs, it can be said that they are the biggest targets in terms of application. Based on this information, it can be said that the roles and effects of these companies according to Gen Y perspective and the consistency and efficiency of HR recruitment practices can be an interesting research topic.

\section{Method}

The goal of this research is to determine the problems of Gen $\mathrm{Y}$ in job interviews and to understand the important HRM mistakes in these processes. This research was designed as a phenomological study, one of the 
qualitative research designs. This method is preferred as it gives the opportunity to make in-depth analysis. Semistructured web-based interviews were conducted to collect data. This research is conducted upon the permission of Akdeniz University, Department of Humanities and Social Sciences, Scientific Research and Publication Ethics Institution. Participants were asked to answer these questions: "What kinds of problems did you experience during recruitment?", "What are the reasons for these problems?" and "How did these problems affect you?". The homogeneous sampling of the research involves a total of 12 Gen Y individuals registered to Linkedin; the individuals who participated in the research graduated from different domains such as engineering, gerontology, econometrics, business or public relations. Qualitative researches prioritize continuing interviews until new opinions are revealed (Arksey and Knight, 1999, p.58); these researches focus on more specific samplings that give the opportunity to have detailed data rather than working on big groups (Coyne, 1997). A similar process is followed in this research, interviews had continued until new opinions were heard; data collection process was completed when data saturation was achieved until in 12 interviews. 7 of the youngest Gen Y representatives in the research are female while 5 of them are male; all of the participants have applied to more than one job. Participants have generally applied to Medium-sized enterprises.

\section{Findings}

Interview notes are analyzed using thematic analysis and the problems experienced by Gen Y were determined. Findings indicate that Gen Y experiences three basic problems during recruitment (see Table 1):

Ethical problems (injustice and wrong attitude/behavior)

Communication problems (information mistakes and feedback deficiencies)

Process management problems (incompetency of the interviewer and coordination deficiency)

There are some metaphors in the interview notes about the recruitment process. Clamp, bleeding wound, torture, and battle are the words used by the candidates while describing the process. According to the candidates, psychological results of the problems they faced during recruitments can be described as anxiety, despair, feeling invaluable, disappointment and stress. It is obvious that individuals of Gen Y, who give importance to the wellbeing and happiness of the employee, are negatively affected when they experience such problems at the beginning of their career.

“.... Waiting for feedback is difficult and boring. It is really disappointing that they don't give even negative feedback."(p.4)

“...I think that such negative processes cause people to lose their hopes and belief in life, they can make people feel invaluable. ”(p.6)

“... There are serious disappointments when interviews are negative one after another.” (p.11)

"Pessimism, concern for the future, anxiety over making a living, not knowing what to do, the feeling offailure at a young age, the feeling of falling behind while everyone else is successful." (p.9)

Gen Y believes that the sources of problems in recruitment processes are incorrect and unprofessional attitudes of HR members, behaviors of business managers involved in job interviews and dysfunctions in HR policies. The significant points determined during interviews can be summarized as such:

Some businesses have no knowledge about global developments or new qualifications. Some new qualifications stated in CVs that are perceived as new skills and abilities by the new generation aren't important for the companies. On the other hand, a skill found to be important by a business may sometimes not be important for the new generation.

The traditional employee management perspective is still valid in medium-sized enterprises. Behaviors of HR members are strict and they sometimes make candidates feel insufficient. On the other hand, department managers that sometimes take part in job interviews don't have very professional attitudes towards the process.

Expectations and priorities of the new generation cannot be understood by the preceding generation. Their interests (such as hobbies or volunteer works) besides technical or professional knowledge aren't important for managers of HR professionals; possible contributions of these qualifications to work performance aren't taken into consideration. 
There are important differences among generations in terms of the way of benefiting from technology and digitalization. Jobs and qualifications are redefined according to technological skills. Qualifications of Gen Y individuals in terms of technology should be efficiently integrated into the job requirements in today's businesses.

Table 1. Problems of gen y during recruitment processes

\begin{tabular}{|c|c|c|c|}
\hline $\begin{array}{l}\text { Main } \\
\text { themes }\end{array}$ & Sub-themes & Explanation & Sample quotations \\
\hline \multirow[b]{2}{*}{$\begin{array}{l}\text { Ethical } \\
\text { problems }\end{array}$} & Injustice & $\begin{array}{l}\text { Recruitments aren't based } \\
\text { on equity or merit. } \\
\text { (Inexperienced individu- } \\
\text { als who have privileges } \\
\text { are preferred!) }\end{array}$ & $\begin{array}{l}\text { "...candidates were treated differently. The ones with } \\
\text { important privileges and the ones with no support. } \\
\text { They were treated differently." (p.5) } \\
\text { "There are so many people who work at jobs that they } \\
\text { are not suitable for; people work in some positions that } \\
\text { they are not qualified for..." (p.3) }\end{array}$ \\
\hline & $\begin{array}{l}\text { Wrong behavior, } \\
\text { attitude }\end{array}$ & $\begin{array}{l}\text { Incorrect, improper be- } \\
\text { haviors and attitudes of } \\
\text { HR members conducting } \\
\text { recruitments } \\
\text { (Sardonic or humiliating } \\
\text { attitudes of HR members } \\
\text { towards the ones who have } \\
\text { recently graduated) }\end{array}$ & $\begin{array}{l}\text { "...people look down on individuals who look for a } \\
\text { job... when they see a person that has recently gradu- } \\
\text { ated (who is naturally shy), they want to oppress } \\
\text { him/her; a kind of humiliation." (p.5) } \\
\text { "... a person who has recently graduated is oppressed, } \\
\text { humiliated and the person responsible for recruitment } \\
\text { makes his/her decision at the beginning of an inter- } \\
\text { view; he/she shows his/her viewpoint with his/her body } \\
\text { language, which is very disturbing." (p.9) }\end{array}$ \\
\hline \multirow[t]{2}{*}{$\begin{array}{l}\text { Communi- } \\
\text { cation prob- } \\
\text { lems }\end{array}$} & Misinformation & $\begin{array}{l}\text { Candidates are intention- } \\
\text { ally or unintentionally } \\
\text { misinformed (Misinfor- } \\
\text { mation about position, } \\
\text { company or working con- } \\
\text { ditions) }\end{array}$ & $\begin{array}{l}\text { ".....Although the issue experience wasn't specifically } \\
\text { mentioned before the interview, it was the main issue } \\
\text { prioritized during the job interview ....(p.8) } \\
\text { "....you start working and problems occur at the very } \\
\text { instant... you are required to carry out some responsi- } \\
\text { bilities that have nothing to do with you; unqualified } \\
\text { employees' duties are given to you... you naturally } \\
\text { don't want to be responsible for them. You see a kind } \\
\text { of deception; job definitions aren't properly made dur- } \\
\text { ing interviews." (p.6) }\end{array}$ \\
\hline & $\begin{array}{l}\text { Feedback defi- } \\
\text { ciency }\end{array}$ & $\begin{array}{l}\text { Not receiving any feed- } \\
\text { back after job interviews } \\
\text { (Interview results aren't } \\
\text { shared with candidates, } \\
\text { the reasons for rejection } \\
\text { aren't explained) }\end{array}$ & $\begin{array}{l}\text { "Not receiving any kind of feedback is quite upsetting. } \\
\text { Having feedback, even if a negative one, makes one } \\
\text { feel valuable. "(p.4) } \\
\text { "...they don't give any feedback, even a negative one. } \\
\text { This is not proper, they should inform candidates } \\
\text { about the result; you just wait and waste time." (p.7) }\end{array}$ \\
\hline \multirow{2}{*}{$\begin{array}{l}\text { Process } \\
\text { manage- } \\
\text { ment prob- } \\
\text { lems }\end{array}$} & $\begin{array}{l}\text { Incompetency of } \\
\text { Interviewer }\end{array}$ & $\begin{array}{l}\text { People who conduct job } \\
\text { interviews aren't qualified } \\
\text { (They don't have any } \\
\text { knowledge about new } \\
\text { skills and proficiencies; } \\
\text { they have old, stereotyped } \\
\text { interview questions, they } \\
\text { cannot reveal candidate } \\
\text { qualifications) }\end{array}$ & $\begin{array}{l}\text { ".....there are different problems such as stereotypical } \\
\text { questions of the interviewer, not being innovative, not } \\
\text { having proper knowledge..." (p.9) } \\
\text { "I believe that problems have resulted from the incom- } \\
\text { petence of interviewers who are inexperienced but re- } \\
\text { sponsible for recruitment." (p.11) }\end{array}$ \\
\hline & $\begin{array}{l}\text { Coordination defi- } \\
\text { ciency }\end{array}$ & $\begin{array}{l}\text { Plan, program, coordina- } \\
\text { tion problems during job } \\
\text { interviews } \\
\text { (Coordination problems } \\
\text { among different interview- } \\
\text { ers responsible for re- } \\
\text { cruitment; mistakes in } \\
\text { time-management during } \\
\text { interviews) }\end{array}$ & $\begin{array}{l}\text { "My only problem was not knowing my exact respond- } \\
\text { ent during the interview" (p.1) } \\
\text { "Human Resources Department is conducting the in- } \\
\text { terviews. They say that the department manager will } \\
\text { be here in a minute, they make you wait for } 2 \text { hours. } \\
\text { Time management is quite insufficient." (p.8) }\end{array}$ \\
\hline
\end{tabular}

\section{Conclusion}

The recruitment process, which is the first step of Human Resources Management, is analyzed through the perspective of Gen Y in this limited research. Results obtained at the end of the research process are in line with the other determinations mentioned in the related literature. Generation Y is over-sensitive towards injustice; people of this generation give reaction to feeling invaluable, give importance to feedback, love innovation, expect 
managers be professional and qualified and prioritize communication, information, and concern (Carless, 2007; Lamm and Meeks, 2009; Tapscott, 2009). This research indicates similar points; it is observed that the representatives of Gen Y experienced a variety of negative experiences during recruitment. According to them, candidates should be appropriately informed in a recruitment process, justice and professionalism should be prioritized, a reliable type of communication should be important (warm, sincere), qualified managers should hold interviews and the process should be professionally coordinated (planned, programmed).

The findings of this study coincide with some theoretical information in the literature. For example, in the interviews, the participants stated that the recruitment is not based on the basis of merit and they see this as a problem. It can be said that Gen Y, who attaches importance to the concept of honesty (Tapscott, 2009) and dislikes injustice (Lamm and Meeks, 2009), wants the people to be recruited to be chosen fairly. Gen Y also does not like to be wrong behaved (Lamm and Meeks, 2009). It can be said that Gen Y's perception of the wrong style or attitudes of the interviewers as a problem is also consistent with the data in the literature. The concept of communication also has an important place in the life of Gen Y (Göktaş and Çarıç̧ı, 2016). In addition, Gen Y attaches importance to the concepts of honesty and transparency when choosing the company to work (Tapcott, 2009). Problems expressed by the participants as misinformation can be associated with this issue. The fact that a generation who needs information (Özer, 2014) and has been aware of all kinds of developments due to the technological opportunities in the period they grew up (Mücevher, 2015) sees it as a problem that they are deprived of information about their workplace, intentionally or unintentionally, or misinform them considered to be compatible with the relevant specifications. Similarly, Gen Y gives importance to feedback (Gurlaş, 2016; Karaaslan, 2014; Özer, 2014). Therefore, the fact that they see not giving feedback as a problem after job interviews is in line with the data in the literature. In the interviews, the participants also stated that the people who conducted the recruitment interviews did not follow the innovations enough/could not keep up with the innovations, and did not have the necessary knowledge and competencies. Gen Y attaches importance to the concept of innovation (Tapscott, 2009) and embraces change. Gen Y, which has more educated people compared to the previous generations, also has higher expectations compared to the previous generations (Sarıkaya and Atsan, 2021). A relationship can be established between this problem, which is described as the incompetency of the interviewer, and the aforementioned characteristics of Gen Y.

As can be understood from the answers given by the participants to the questions, recruitment processes are difficult processes that have serious effects on human life. An example of this idea is that the participants express their recruitment processes with metaphors such as a clamp, bleeding wound, torture, and battle, and how the processes make them feel with concepts such as excitement, sadness, anxiety, hopelessness, worthlessness, disappointment, and stress. From this point of view, in an environment where recruitment processes are of great importance for both companies looking for personnel and applicant candidates, it is thought that making improvements in the process will be beneficial for both parties in practice. In line with the findings of this research, some improvement suggestions can be made to the businesses that have problems in recruitment. For example, recruitment should be done fairly, taking into account factors such as the success of the candidate and having job-related competencies, and the applicants should be made to feel that the elections were made in a fair and merit-based manner. In addition, the authorities should communicate with the candidates in a friendly way by emphasizing empathy, and avoiding approaching the candidates in an offensive, condescending, humiliating tone. Candidates should be informed honestly and adequately about the job, working conditions, or other aspects of the process. Interviews should be conducted by competent people, interviews and other stages of the process should be planned meticulously, taking into account the interests of the candidates, and should be carried out in a disciplined manner within a certain programmed framework. It is thought that these and similar issues will contribute to the improvement of the process.

Besides the problems experienced by candidates during recruitment, findings of the research indicate that the current job and qualification definitions should be revised according to the aspects of the new generations. Although there are various differences between the generations in many aspects (Sarıkaya and Atsan, 2021), it is seen that Gen X, Y, and Z show similarities in these elements (Glazer et al., 2019; Chillakuri, 2020; Yaşar and Demir, 2021). For example, as well as technical skills and experience levels of candidates, hobbies, abilities and other qualifications that can add additional value to the work should be considered as a dimension of talent management. Traditional HR perspective followed by medium-sized enterprises actually causes transaction costs as they cannot benefit from the emerging skills that will be provide competitive advantage to the enterprise. As a result, it can be said that recruitment process is the first step of the psychological contracts between employees and businesses; based on this information, it should be noted that the employer brand value of a business is formed in the first 
connection established with potential candidates. Because of these significant points, it is important to professionally manage recruitment processes for all applicants, which show the reputation of HRM and it is necessary to support and improve the knowledge of HR experts according to the fast-changing and modern conditions of today's business world.

\section{Author contribution statements}

Author contributed all to the design and implementation of the research, to the analysis of the results and to the writing of the manuscript.

\section{Disclosure statement}

No potential conflict of interest was reported by the author.

\section{Ethics committee approval}

This research has Ethics Committee Approval from Akdeniz University with 03/05/2019 date and 104 number. All responsibility belongs to the researchers.

\section{Acknowledgements}

I would like to thank Prof. Dr. Ferda ERDEM for her support.

\section{References}

Adıgüzel, O., Batur, H. Z. \& Ekşili, N. (2014). Kuşakların değişen yüzü ve Y kuşağı ile ortaya çıkan yeni çalışma tarzı: Mobil Yakalılar. Süleyman Demirel Üniversitesi Sosyal Bilimler Enstitüsü Dergisi, 1(19). 165-182.

Arksey, H. \& Knight, P. (1999). Interviewing for social scientists. New York: Sage Publications.

Arsenault, P. M. (2004). Validating generational differences: A legitimate diversity and leadership issue. The Leadership \& Organizational Development Journal, 25(2). 124-141.

Bosco, S. M. \& Harvey, D. M. (2013). Generational effects on recruitment and workplace productivity. Proceedings of the northeast business \& economics association, New Hampshire, Washington (17-20).

Carless, S. A. (2007). Graduate recruitment and selection in Australia. International Journal of Selection and Assessment, 15(2). 153-166.

Chillakuri, B. (2020). Understanding Generation Z expectations for effective onboarding. Journal of Organizational Change Management, 33(7). 1277-1296.

Coyne, I. T. (1997). Sampling in qualitative research. Purposeful and theoretical sampling; merging or clear boundaries?. Journal of Advanced Nursing, 26(3). 623-630.

D’Netto, B. \& Ahmed, E. (2012). Generation Y: Human resource management implications. Journal of Business and Policy Research, 1(1). 1-9.

De Hauw, S. \& De Vos, A. (2010). Millennials' career perspective and psychological contract expectations: Does the recession lead to lowered expectations?. Journal of Business and Psychology, 25(2). 293-302.

Deloitte (2018). Deloitte Y kuşăğ araştırması 2018. Retrieved from https://www2.deloitte.com/tr/tr/pages/about-deloitte/articles/deloitte-y-kusagi-arastirmasi-2018.html. Accessed on October, 2021.

Drago, J. P. \& Cunningham, G. K. (2006). Generational theory: Implications for recruiting the millennials. Carlisle: US Army War College.

Dries, N., Pepermans, R. \& De Kerpel, E. (2008). Exploring four generations' beliefs about career: Is "satisfied" the new "successful?. Journal of Managerial Psychology, 23(8). 907-928.

Eisner, S. P. (2005). Managing generation Y. S.A.M. Advanced Management Journal, 70(4). 4-15.

Glazer, S., Mahoney, A. C. \& Randall, Y. (2019). Employee development's role in organizational commitment: A preliminary investigation comparing generation $\mathrm{X}$ and millennial employees. Industrial and Commercial Training, 51(1). 1-12.

Göktaş, P. \& Çarıkçı, İ. H. (2016). Siyasi liderlerden beklenen liderlik ve iletişim tarzları: Y kuşağı üzerine bir araştırma. Ankara Üniversitesi SBF Dergisi, 71(3). 855-888.

Gurlaş, M. S. (2016). Jenerasyon teorisine göre $x$ ve y kuşakların örgütsel bağlllık, iş tatmini ve işten ayrılma niyeti farklılıklarının incelenmesi; Kamuda vergi dairesi çalışanları üzerinde bir araştırma. Master's Thesis, Nişantaşı University, İstanbul. 
Hiltrop, J. M. (1999). The quest for the best: Human resource practices to attract and retain talent. European Management Journal, 17(4). 422-430.

Hurst, J. \& Good, L. (2009). Generation Y and career choice. Career Development International, 14(6). 570-593.

Huybers, C. M. (2011). The recruitment and retention of generation Y. Master's Thesis, University of Wisconsin-Stout, Menomonie, WI.

Imperatori, B. \& Bissola, R. (2010). Generation Y at work: The role of e-HRM in building positive work attitudes. Proceedings of the third european academic workshop on electronic human resource management. Bamberg. Germany (pp. 1-22).

Inglehart, R. (1977). The silent revolution: Changing values and political styles among western publics. Princeton: Princeton University Press.

Karaaslan, S. (2014). Kuşaklararası farklılıkları örgütler üzerinden anlamak. Master’s Thesis, Ankara University, Ankara.

Kultalahti, S. \& Viitala, R. (2015). Generation Y - challenging clients for HRM?. Journal of Managerial Psychology, 30(1). 101-114.

Lamm, E. \& Meeks, M. D. (2009). Workplace fun: The moderating effects of generational differences. Employee Relations, 31(6). 613-631.

Loiacono, E., Djamasbi, S., Tulu, B. \& Pavlov, O. (2011). Why virtual job recruitment is not well accepted by Generation Y? - A case study on second life. International conference on human-computer interaction in Heidelberg. Springer, Berlin (pp. 245-254).

Luscombe, J., Levis, I. \& Biggs, H. C. (2013). Essential elements for recruitment and retention: Generation Y. Education + Training, 55(3). 272-290.

Mannheim, K. (1952). The problem of generations. In P. Kecskemeti (Ed.), Essays on the sociology of knowledge (pp. 276320). London: Routledge \& Kegan Paul, London.

Mücevher, M. H. (2015). X ve Y kuşağının birbirlerine karşı özellik ve etkileşim algıları: SDÜ örneği. Master's Thesis, Süleyman Demirel University, Isparta.

Ng, E. S. \& Parry, E. (2016). Multigenerational research in human resource management. In M. R. Buckley, J. R. B. Halbesleben \& A. R. Wheeler (Eds.), Research in personnel and human resources management (Vol. 34, pp. 1-41). Bingley: Emerald Group Publishing Limited.

Ng, E. S. W., Schweitzer, L. \& Lyons, S. T. (2010). New generation, great expectations: A field study of the millennial generation. Journal of Business and Psychology, 25(2). 281-292.

Özer, P. S. (2014). Kuşak farkının işe ilişkin değer ve tutumlar açısından incelenmesine yönelik bir araştırma. Finans Politik \& Ekonomik Yorumlar, 51(589). 53-68.

Pinzaru, F., Mihalcea, A. \& Zbuchea, A. (2017). Recruiting and motivating millennials: Empirical insights for managers. Proceedings of the 11th international management conference in Bucharest, Romania (pp. 729-737).

Reeves, T. C. \& Oh, E. (2007). Generational differences. In J. M. Spector, M. D. Merrill, J. M. Merrienboer \& M. P. Driscoll (Eds.), Handbook of research on educational communications and technology (p. 295-303). Manwah: Lawrence Erlbaum Associates.

Sarıkaya, O. \& Atsan, N. (2021). Karar verme stili ve risk alma eğilimi: X ve Y kuşakları açısından bir değerlendirme. Süleyman Demirel Üniversitesi Vizyoner Dergisi, 12(30). 599-611.

Smola, K. W. \& Sutton, C. D. (2002). Generational differences: Revisiting generational work values for the new millennium. Journal of Organizational Behavior, 23. 363-382.

Strauss, W. \& Howe, N. (1991). Generations: The history of America's future, 1584 to 2069. New York: William Morrow.

Tapscott, D. (2009. Grown up digital: How the net generation is changing your world. New York: McGraw-Hill.

Turkish Statistical Institute (2019). İşzücü istatistikleri, Ağustos 2019. Retrieved from https://data.tuik.gov.tr/Bulten/Index? $p=$ Isgucu-Istatistikleri-Agustos-2019-30692. Accessed on October, 2021.

Warmerdam, A., Lewis, I. \& Banks, T. (2015). Gen Y recruitment. Education + Training, 57(5). 560-574.

Wong, M., Gardiner, E., Lang, W. \& Coulon, L. (2008). Generational differences in personality and motivation: Do they exist and what are the implications for the workplace?. Journal of Managerial Psychology, 23(8). 878-890.

Yaşar, E. \& Demir, M. (2021). Z kuşağının işyeri seçiminde işveren markasının etkisi: Otel işletmeleri örneği. Pamukkale Üniversitesi Sosyal Bilimler Enstitüsü Dergisi, 46. 1181-1195.

Yi, X., Ribbens, B., Fu, L. \& Cheng, W. (2015). Variation in career and workplace attitudes by generation, gender, and culture differences in career perceptions in the United States and China. Employee Relations, 37(1). 66-82. 